DOI: $\square$ https://doi.org/10.15407/techned2020.04.035

\title{
FORMATION OF DYNAMIC MODES OF FULL-CONTROLLED HYBRID ENERGY STORAGE SYSTEM FOR ELECTRIC VEHICLES
}

Journal

Publisher

ISSN

Issue

Pages
Tekhnichna elektrodynamika

Institute of Electrodynamics National Academy of Science of Ukraine 1607-7970 (print), 2218-1903 (online)

No 4, 2020 (July/August)

$35-40$

\section{Authors}

S. Peresada*, Ye. Nikonenko* ${ }^{\star \star}$ M. Zhelinskyii ${ }^{\star \star *}$, V. Reshetnyk ${ }^{\star \star \star *}$

National Technical University of Ukraine "Igor Sikorsky Kyiv Polytechnic Institute",

Peremohy ave., 37, 03056, Kyiv, Ukraine,

e-mail: sergei.peresada@gmail.com

* ORCID ID : https://orcid.org/0000-0001-8948-722X

** ORCID ID : https://orcid.org/0000-0003-2379-5566

*** ORCID ID : https://orcid.org/0000-0003-4862-1802

**** ORCID ID : https://orcid.org/0000-0002-8428-0446

\section{Abstract}

In this paper, the results of the experimental investigations of the dynamic modes of the hybrid energy storage system for electric vehicles are shown which is based on the batteries and supercapacitors. The recommendations on the formation of dynamical modes are presented. The load current is formed based on diagrams of the motor torque and speed which correspond to the movement of a typical electric vehicle. It is experimentally shown that hybrid energy storage systems with a fixed configuration of the decoupling filter improve the batteries operation conditions, comparing with the battery-only source, but cannot guarantee effective currents distribution for all dynamic modes of an electric vehicle. References 10, figures 4 .

Key words: hybrid energy storage system, electric vehicle, distribution filter, dynamic modes forming. 
Received: 28.02.2020

Accepted: 14.04 .2020

Published: 26.06.2020

\section{References}

1. Hemmati R., Saboori, H. Emergence of hybrid energy storage systems in renewable energy and transport applications. Renewable and Sustainable Energy Reviews. 2016. Vol. 65. Pp. 11-23. DOI: .org/10.1016/j.rser.2016.06.029

https://doi

2. Peresada S., Nikonenko Y., Kovbasa S., Kuznietsov A., Pushnitsyn D. Rapid prototyping station for batteries-supercapacitors hybrid energy storage systems. IEEE 39th International Conference on Electronics and Nanotechnology (ELNANO-2019). Ukraine. Kyiv. April, 16-18. 2019. Pp. 826-831. DOI: https://doi.org/10.1109/ELNANO.2019.8783731

3. Zhang C., Min H., Yu Y., Wang D., Luke J., Opila D., Saxena S. Using CPE function to size capacitor storage for electric vehicles and quantifying battery degradation during different driving cycles. Energies. 2016. Vol. 9. Pp. 1-23. DOI: https://doi.org/10.3390/en9110903 4. Kollimalla S. K., Mishra M. K., Ukil A., Gooi H. B. DC grid voltage regulation using new HESS control strategy. IEEE Transactions on Sustainable Energy. April, 2017. Vol. 8. No 2. Pp. 772-781.

DOI: https://doi.org/10.11 09/TSTE.2016.2619759

5. Peresada S., Kovbasa S., Pristupa D., Pushnitsyn D., Nikonenko Y. Nonlinear control of voltage source AC-DC and DC-DC boost converters. Visnyk Natsionalnoho tekhnichnoho universiteta Kharkivskii politekhnichnyi instytut. Problemy avtomatyzovanoho elektropryvodu. Teoriia ta praktyka. Sylova elektronika ta energoefektyvnist . Kharkiv. 2017. No 27. Pp. 84-88. (Rus)

DOI:

https://doi.org/10.1109/UKRCON.2017.8100532

6. Peresada S., Kovbasa S., Nikonenko Y., Bozhko S. Concept of experimental research for electrical vehicle electromechanical systems with hybrid energy storages. Tekhnichna Elektrodynamika 2018. No 5. Pp. 57-60. (Ukr) DOI: https://doi.org/10.15407/techned2018.05.057 7. Zhang S., Xiong R., Zhou X. Comparison of the topologies for a hybrid energy-storage system of electric vehicles via a novel optimization method. Sci. China Technological Sci. 2015. 
Vol. 58. No 7. Pp. 1173-1185.

DOI:

https://doi.org/10.1007/s11431-015-5843-y

8. Akar F., Tavlasoglu Y., Vural B. An energy management strategy for a concept battery/ultracapacitor electric vehicle with improved battery life. IEEE Transactions on

Transportation Electrification

2017. Vol. 3. No 1. Pp. 191-200.

DOI:

https://doi.org/10.1109/TTE.2016.2638640

9. Tremblay O. Experimental validation of a battery dynamic model for EV applications. World Electric Vehicle Journal

. May, 2009. Vol. 3. Pp. 289-298.

DOI:

https://doi.org/10.3390/wevj3020289

10. Keil P., Jossen A. Impact of dynamic driving loads and regenerative braking on the aging of lithium-ion batteries in electric vehicles. Journal of the electrochemical society. 2017. Vol. 164.

No 13. Pp. A3081-A3092.

DOI:

https://doi.org/10.1149/2.0801713jes

$\underline{\text { PDF }}$

This work is licensed under a Creative Commons Attribution-NonCommercial-NoDerivatives $\underline{4.0 \text { International License }}$ 